\title{
Effect of Liquid Bioinoculants and Inorganic Source of Nutrients on Biomass Production and Quality of Annual Moringa (Moringa oleifera Lam.) var. PKM - 1
}

\author{
V. Viji, R. Balakumbahan", V. Lakshmanan, R. Poorniammal and E.K. Naik
}

Horticultural College and Research Institute, Periyakulam East 625 604, Theni District, Tamilnadu, India

*Corresponding author

\begin{abstract}
A B S T R A C T
Experiment on effect of liquid bioinoculants on biomass production of Annual moringa (Moringa oleifera Lam.) var. PKM - 1 was carried out during October 2016- May 2017 at Horticultural College and Research Institute, Tamil Nadu Agricultural University,

\section{Keywords}

Moringa, Liquid bioinoculants, Inorganic fertilizers, Biomass, Quality

Article Info

Accepted: 04 May 2018 Available Online: 10 June 2018

Periyakulam. Liquid biofertilizers viz., Azospirillum brasilense (Azos), Bacillus megaterium (PSB), Bacillus mucilagenosus (KSB) and Methylobacterium extorquens (Pink Pigmented Facultative Methylotrophs -PPFM) as bioinoculants along with graded level of recommended dose of inorganic fertilizers (75\%, 100\% and $125 \%$ of RDF) were used in the experiment. Inorganic water soluble fertilizers in four stages in all the treatments on 20 DAS, 50 DAS, 80 DAS and 110 DAS, the liquid bio inoculants Azospirillum, PSB and KSB were 15 days after the application of inorganic fertilizers were applied through drip irrigation. PPFM is applied through foliar application as per the treatment along with other microbial inoculants. Plant growth and biomass yield parameters were recorded in periodic intervals and the data collected were statistically analyzed. The results revealed highest plant height, number of branches per plant, number of leaves per plant, leaf area, chlorophyll content, chlorophyll stability index was observed in the plants treated with $125 \%$ of RDF along with all microbial inoculants used for the study. Besides the same treatment combination also recorded fresh and dry leaf biomass in all the harvests done during the experiment.
\end{abstract}

\section{Introduction}

Moringa oleifera Lam. a species of the family moringaceae is widely cultivated in many tropical and subtropical countries because of its high nutraceuticals value (Ponnuswami et al., 2010). Moringa is referred as Mother's Best Friend, Horse Radish tree, Miracle tree and Murungai in Tamil. Moringa is one of the important commercial vegetable crops of
Tamil Nadu widely grown commercially for its edible pods and leaves. It has significant economic importance because of its several industrial and medicinal applications. The pulp of Moringa wood is one of the raw material in paper, cellophane and textile production. The stem exudes (Resin) from moringa is used in calico printing and seeds powder is used to flocculate contaminants and purification of drinking water. Ben oil 
extracted from moringa seed kernel is one of the best for fine machine lubrication and in the manufacture of cosmetics (Tsaknis et al., 1999). Leaves of moringa are a treasure source of nutrients for rural populations (Lockett et al., 2000). Moringa leaves are rich in protein and amino acid composition, which is suitable for human and cattle nutrition (Freiberger et al., 1998). $100 \mathrm{~g}$ of moringa leaves contain four times more vitamin A than the same quantity of carrots, four times of calcium in a cup of milk, $100 \mathrm{~g}$ more iron than of spinach, seven times of vitamin $\mathrm{C}$ in $100 \mathrm{~g}$ of oranges and three times of potassium in $100 \mathrm{~g}$ of bananas. The protein quality of moringa leaves also rivals that of milk and eggs (Fahey, 2005; Fuglie, 2001).

It provides rich and rare combinations of nutrients, amino acids, antioxidants and antiinflammatory properties used for nutrition and healing. Since, 1998 the World Health Organization has promoted moringa as an alternative to imported food supplies to treat malnutrition (Johnson, 2005; Manzoor et al., 2007). Though there is a growing demand for the moringa leaves organized cultivation with proper nutrient management is lacking which leads the quality variation in the industries where it is processed. With a view to standardize the nutrient management with inorganic and biofertilizers, this study was conducted to investigate the effect of liquid bioinoculants along with inorganic sources of nutrients on the growth and yield of moringa for leaf biomass production.

\section{Materials and Methods}

Investigation on effect of liquid biofertilizers viz., Azospirillum brasilense (Azos), Bacillus megaterium [Phosphorus Solubilizing Bacteria (PSB)], Bacillus mucilagenosus [Potassium solubilizing bacteria (KSB)] and Methylobacterium extorquens (PPFM) along with graded level of recommended dose of inorganic fertilizers (RDF) was carried out at the Department of Vegetable crops, Horticultural College and Research Institute, Periyakulam, TNAU during 2016-2017. Moringa var PKM -1 was used for the study. Azospirillum brasilense (Azos), Bacillus megaterium (PSB), Bacillus mucilagenosus (KSB) and Methylobacterium extorquens (PPFM) were used as microbial inoculants. Liquid form of Azospirillum $\left(10^{9}\right.$ cells $\left./ \mathrm{ml}\right)$ and Phosphorus Solubilizing Bacteria $\left(10^{9} \mathrm{cell} / \mathrm{s} / \mathrm{ml}\right)$ are obtained from the microbiology laboratory of Horticultural College and Research Institute, Periyakulam. Potassium Solubilizing Bacteria ( $10^{9}$ cells/ ml) and Methylobacterium extorquens $\left(10^{9}\right.$ cells $\left./ \mathrm{ml}\right)$ are collected from the Department of Agricultural Microbiology, Agricultural College and Research Institute, Madurai. The details of the treatments imposed are as follows. Raised beds of $9 \mathrm{~m}$ length, $1.60 \mathrm{~m}$ width and $0.20 \mathrm{~m}$ height were prepared with drip and fertigation facilities. The moringa seeds were sown in raised bed at a spacing of $40 \times 20 \mathrm{~cm} .25 \mathrm{t} \mathrm{ha}^{-1}$ of farm yard manure was applied as basal and incorporated. The experiment was laid out in a Randomized Block Design with three replications. The recommended dose of 270:45:90 kg $\mathrm{N}: \mathrm{P}_{2} \mathrm{O}_{5}: \mathrm{K}_{2} \mathrm{O}$ ha $^{-1}$ (Jaison, 2016) in the form of inorganic water soluble fertilizers were applied in four split doses i.e., 20, 50, 80 and 110 days after sowing as follows

\section{Water soluble fertilizer schedule}

The biofertilizers of Azospirillum (Azos), Phosphobacteria (PSB) and potassium solubilizing bacteria (KSB) in liquid form were applied at the rate of $500 \mathrm{ml} \mathrm{ha}^{-1}$ through drip irrigation in four split doses on 15 days after inorganic fertilizer application $(35,65$, 95 and 125 days after sowing) and PPFM isolates was diluted at 1:100 ratio with water mixed with $0.1 \%$ surfactant and sprayed with hand sprayer at 35, 65, 95 and 125 days after 
sowing as per the treatment requirement. First harvest of leaves was commenced at 60 days after sowing, subsequent leaf harvest was done at 45 days interval and totally three harvests were made during the study period. Observations on different growth, physiological and yield parameters were recorded at all the three harvests. The analysis for the experimental data collected was done as per Panse and Sukhatme (1978).

\section{Results and Discussion}

Effect of liquid bioinoculants along with graded level of recommended dose of inorganic fertilizers had shown significant influence on biomass production of Annual moringa var. PKM-1. Plant growth attributes viz., plant height, number of leaves and leaf area were highest with $125 \%$ of recommended dose of fertilizers + Azos + PSB + KSB + PPFM. The better growth of moringa may be due to rapid release and increased availability of $\mathrm{N}, \mathrm{P}$ and $\mathrm{K}$ at the early stages of the plants. The liquid biofertilizer application might have helped to increase the biological nitrogen fixation, availability of phosphorus and potassium required for growth. These results are in conformity with Nanthakumar and Veeraragavathatham (2000) in brinjal, Gowda et al., (2002) in chilli and shams et al., (2013) in lettuce. Significant increase in plant growth characters might also be due to the presence of readily available form of nutrients at higher quantities in rhizosphere soil and production of plant growth promoting substances (Khan and Chattopadhyay, 2009).

Leaf area is having direct correlation with photosynthetic efficiency in plants. Total leaf area per plant is often a useful measurement in bio-productivity studies. In the present study, leaf area was significantly influenced combined application of inorganic and biofertilizers and plants supplied with $125 \%$ $\mathrm{RDF}+A z o s+\mathrm{PSB}+\mathrm{KSB}+\mathrm{PPFM}$ recorded the highest leaf area. This could be attributed to the production of greater number of photosynthetically active leaves because of adequate nitrogen uptake by plants which might have led to higher metabolic activity resulting in higher production of carbohydrates and phytohormones which is in line with the report of Padmapriya and Anu Geetham (2015). Highest leaf area index recorded in the treatment RDF $125 \%+$ Azos + $\mathrm{PSB}+\mathrm{KSB}+\mathrm{PPFM}$ might be due to continuous and uninterrupted supply of water and nutrients through fertigation which favours easy availability of nutrients from water soluble fertilizers. Besides the organic compounds released by the microorganisms which play an important role in the uptake of mineral nutrient for better plant growth (Manivannan and Singh, 2004).

Photosynthetic rate of a plant is greatly influenced by the green pigment chlorophyll which is also considered as an index of the metabolic efficacy of plants. A slight fluctuation in chlorophyll content is sufficient to trigger changes in physiological processes of plants, particularly photosynthesis. Presence ensured balanced nutrition and biofertilizers which made the applied nutrients into easily available might have resulted in well-developed leaves with greater chlorophyll content. It might be due to more accumulation of assimilates. More over potassium is an integral part for the development of chlorophyll, plays an important role in photosynthesis, which is converting carbon dioxide and hydrogen into sugars, for translocation of sugars, and for starch formation, and also metabolic activities of plants (Meena et al., 2016). Besides, biofertilizers, the commonly called microbial inoculants are capable of mobilizing important nutritional elements in the soil from nonusable to usable form through biological processes might be the reason for better chlorophyll content in moringa leaves (Table 1-4). 
Table.1 Effect of liquid bioinoculants on plant growth characters of annual moringa var PKM-1

\begin{tabular}{|c|c|c|c|c|c|c|c|c|c|c|c|c|}
\hline \multirow[t]{2}{*}{ Treatments } & \multicolumn{4}{|c|}{ Plant height $(\mathrm{Cm})$} & \multicolumn{4}{|c|}{ Number of leaves plant ${ }^{-1}$} & \multicolumn{4}{|c|}{ Leaf area plant ${ }^{-1}\left(\mathrm{~cm}^{2}\right)$} \\
\hline & $\begin{array}{c}\text { I } \\
\text { harvest }\end{array}$ & $\begin{array}{c}\text { II } \\
\text { harvest }\end{array}$ & $\begin{array}{c}\text { III } \\
\text { harvest }\end{array}$ & Mean & $\begin{array}{c}\text { I } \\
\text { harvest }\end{array}$ & $\begin{array}{c}\text { II } \\
\text { harvest }\end{array}$ & $\begin{array}{c}\text { III } \\
\text { harvest }\end{array}$ & Mean & $\begin{array}{c}\text { I } \\
\text { harvest }\end{array}$ & $\begin{array}{c}\text { II } \\
\text { harvest }\end{array}$ & $\begin{array}{c}\text { III } \\
\text { harvest }\end{array}$ & Mean \\
\hline $\mathbf{T}_{1}$ & 137.48 & 132.56 & 127.95 & 132.66 & 16.54 & 17.03 & 20.06 & 17.88 & 526.11 & 641.36 & 645.95 & 604.47 \\
\hline $\mathbf{T}_{2}$ & 155.02 & 144.70 & 141.01 & 146.91 & 17.30 & 17.98 & 21.63 & 18.97 & 555.93 & 683.66 & 724.64 & 654.74 \\
\hline $\mathbf{T}_{3}$ & 161.76 & 155.15 & 152.54 & 156.48 & 18.56 & 19.28 & 23.74 & 20.53 & 686.59 & 723.16 & 756.52 & 722.09 \\
\hline $\mathbf{T}_{4}$ & 141.33 & 135.78 & 128.55 & 135.22 & 16.72 & 17.30 & 20.20 & 18.07 & 537.40 & 643.04 & 657.45 & 612.63 \\
\hline $\mathbf{T}_{5}$ & 138.81 & 134.12 & 131.08 & 134.67 & 16.78 & 17.56 & 20.42 & 18.25 & 532.73 & 670.32 & 638.28 & 613.78 \\
\hline$T_{6}$ & 156.66 & 146.55 & 143.38 & 148.86 & 17.62 & 18.17 & 22.36 & 19.38 & 576.52 & 655.42 & 704.10 & 645.35 \\
\hline$T_{7}$ & 165.48 & 158.71 & 155.26 & 159.82 & 18.95 & 20.52 & 24.45 & 21.31 & 710.12 & 746.83 & 769.89 & 742.28 \\
\hline $\mathrm{T}_{8}$ & 144.42 & 138.68 & 132.99 & 138.70 & 16.76 & 17.44 & 20.80 & 18.33 & 562.41 & 654.34 & 647.97 & 621.57 \\
\hline SE (d) & 2.49 & 2.37 & 2.31 & 2.39 & 0.29 & 0.30 & 0.36 & 0.32 & 9.78 & 11.22 & 11.48 & 10.82 \\
\hline CD (0.05) & 5.33 & 5.09 & 4.95 & 5.12 & 0.62 & 0.64 & 0.77 & 0.68 & 20.98 & 24.06 & 24.63 & 23.21 \\
\hline
\end{tabular}

Table.2 Effect of liquid bioinoculants on chlorophyll content and leaf area index of annual moringa var PKM-1

\begin{tabular}{|c|c|c|c|c|c|c|c|c|c|c|c|c|}
\hline \multirow[t]{2}{*}{ Treatments } & \multicolumn{4}{|c|}{ Total chlorophyll content ( $\left.\mathrm{mg} \mathrm{g}^{-1}\right)$} & \multicolumn{4}{|c|}{ Chlorophyll stability index (\%) } & \multicolumn{4}{|c|}{ Leaf area index } \\
\hline & $\begin{array}{c}\text { I } \\
\text { harvest }\end{array}$ & $\begin{array}{c}\text { II } \\
\text { harvest }\end{array}$ & $\begin{array}{c}\text { III } \\
\text { harvest }\end{array}$ & Mean & $\begin{array}{c}\text { I } \\
\text { harvest }\end{array}$ & $\begin{array}{c}\text { II } \\
\text { harvest }\end{array}$ & $\begin{array}{c}\text { III } \\
\text { harvest }\end{array}$ & Mean & $\begin{array}{c}\text { I } \\
\text { harvest }\end{array}$ & $\begin{array}{c}\text { II } \\
\text { harvest }\end{array}$ & $\begin{array}{c}\text { III } \\
\text { harvest }\end{array}$ & Mean \\
\hline $\mathbf{T}_{1}$ & 2.66 & 2.83 & 2.92 & 2.80 & 74.53 & 80.72 & 83.36 & 79.54 & 0.66 & 0.80 & 0.81 & 0.76 \\
\hline$T_{2}$ & 2.85 & 3.04 & 3.08 & 2.99 & 75.54 & 81.66 & 85.96 & 81.05 & 0.69 & 0.85 & 0.91 & 0.82 \\
\hline $\mathbf{T}_{3}$ & 3.11 & 3.33 & 3.42 & 3.29 & 81.44 & 83.28 & 87.95 & 84.22 & 0.85 & 0.90 & 0.95 & 0.90 \\
\hline $\mathbf{T}_{4}$ & 2.70 & 2.83 & 2.94 & 2.82 & 76.79 & 80.81 & 85.50 & 81.03 & 0.67 & 0.80 & 0.82 & 0.76 \\
\hline$T_{5}$ & 2.86 & 2.98 & 3.25 & 3.03 & 80.85 & 82.43 & 89.04 & 84.11 & 0.67 & 0.84 & 0.80 & 0.77 \\
\hline$T_{6}$ & 3.01 & 3.30 & 3.45 & 3.25 & 83.16 & 83.85 & 89.78 & 85.60 & 0.73 & 0.82 & 0.88 & 0.81 \\
\hline$T_{7}$ & 3.18 & 3.53 & 3.61 & 3.44 & 85.38 & 85.60 & 91.42 & 87.47 & 0.88 & 0.93 & 0.96 & 0.92 \\
\hline $\mathrm{T}_{8}$ & 2.83 & 2.95 & 3.08 & 2.95 & 82.12 & 83.03 & 89.70 & 84.95 & 0.70 & 0.82 & 0.81 & 0.78 \\
\hline SE (d) & 0.05 & 0.06 & 0.08 & 0.05 & 0.75 & 0.80 & 0.65 & 1.38 & 0.01 & 0.01 & 0.01 & 0.02 \\
\hline CD (0.05) & 0.12 & 0.12 & 0.17 & 0.11 & 1.62 & 1.72 & 1.40 & 2.95 & 0.03 & 0.03 & 0.03 & 0.05 \\
\hline
\end{tabular}


Table.3 Effect of liquid bioinoculants on fresh and dry biomass yield of annual moringa var PKM-1

\begin{tabular}{|c|c|c|c|c|c|c|c|c|c|c|c|c|}
\hline \multirow[t]{2}{*}{ Treatments } & \multicolumn{4}{|c|}{ Fresh leaf yield plot ${ }^{-1}(\mathrm{~kg})$} & \multicolumn{4}{|c|}{ Dry leaf yield plot ${ }^{-1}(\mathrm{~kg})$} & \multicolumn{4}{|c|}{ Estimated dry leaf yield $\mathrm{ha}^{-1}$} \\
\hline & $\begin{array}{c}\text { I } \\
\text { harvest }\end{array}$ & $\begin{array}{c}\text { II } \\
\text { harvest }\end{array}$ & $\begin{array}{c}\text { III } \\
\text { harvest }\end{array}$ & Mean & $\begin{array}{c}\text { I } \\
\text { harvest }\end{array}$ & $\begin{array}{c}\text { II } \\
\text { harvest }\end{array}$ & $\begin{array}{c}\text { III } \\
\text { harvest }\end{array}$ & Mean & $\begin{array}{c}\text { I } \\
\text { harvest }\end{array}$ & $\begin{array}{c}\text { II } \\
\text { harvest }\end{array}$ & $\begin{array}{c}\text { III } \\
\text { harvest }\end{array}$ & Mean \\
\hline$T_{1}$ & 7.89 & 9.28 & 9.81 & 9.0 & 1.55 & 1.75 & 1.89 & 1.73 & 1.08 & 1.22 & 1.31 & 1.20 \\
\hline $\mathbf{T}_{2}$ & 9.49 & 10.59 & 11.4 & 10.5 & 1.86 & 2 & 2.19 & 2.02 & 1.29 & 1.39 & 1.52 & 1.40 \\
\hline $\mathbf{T}_{3}$ & 11.7 & 11.82 & 12.64 & 12.1 & 2.23 & 2.29 & 2.43 & 2.32 & 1.55 & 1.59 & 1.69 & 1.61 \\
\hline $\mathbf{T}_{4}$ & 8.01 & 9.78 & 10.26 & 9.4 & 1.57 & 1.84 & 1.97 & 1.79 & 1.09 & 1.28 & 1.37 & 1.25 \\
\hline $\mathbf{T}_{5}$ & 8.59 & 10.14 & 10.29 & 9.7 & 1.68 & 1.91 & 1.98 & 1.86 & 1.17 & 1.33 & 1.38 & 1.29 \\
\hline$T_{6}$ & 10.14 & 10.93 & 12.36 & 11.1 & 1.99 & 2.06 & 2.38 & 2.14 & 1.38 & 1.43 & 1.65 & 1.49 \\
\hline$T_{7}$ & 12.12 & 12.61 & 13.01 & 12.6 & 2.34 & 2.38 & 2.5 & 2.41 & 1.63 & 1.65 & 1.74 & 1.67 \\
\hline $\mathrm{T}_{8}$ & 9.54 & 9.88 & 11.09 & 10.2 & 1.87 & 1.86 & 2.13 & 1.95 & 1.30 & 1.29 & 1.48 & 1.36 \\
\hline SE (d) & 0.16 & 0.18 & 0.19 & 0.30 & 1.02 & 0.60 & 0.53 & 0.72 & 0.02 & 0.03 & 0.03 & 0.04 \\
\hline CD (0.05) & 0.35 & 0.38 & 0.41 & 0.65 & 2.20 & 1.28 & 1.14 & 1.54 & 0.05 & 0.05 & 0.05 & 0.08 \\
\hline
\end{tabular}

* Plot size is $14.4 \mathrm{~m}^{2}$ (9m length $x 1.6 \mathrm{~m}$ width)

Table.4 Effect of liquid bioinoculants on leaf nutrient content of annual moringa var PKM-1

\begin{tabular}{|c|c|c|c|c|c|c|c|c|c|c|c|c|}
\hline \multirow[t]{2}{*}{ Treatments } & \multicolumn{4}{|c|}{ Calcium content $(\%)$} & \multicolumn{4}{|c|}{ Iron content (ppm) } & \multicolumn{4}{|c|}{ Ascorbic acid content $\left(\mathrm{mg} 100 \mathrm{~g}^{-1}\right)$} \\
\hline & $\begin{array}{c}\text { I } \\
\text { harvest }\end{array}$ & $\begin{array}{c}\text { II } \\
\text { harvest }\end{array}$ & $\begin{array}{c}\text { III } \\
\text { harvest }\end{array}$ & Mean & $\begin{array}{c}\text { I } \\
\text { harvest }\end{array}$ & $\begin{array}{c}\text { II } \\
\text { harvest }\end{array}$ & $\begin{array}{c}\text { III } \\
\text { harvest }\end{array}$ & Mean & $\begin{array}{c}\text { I } \\
\text { harvest }\end{array}$ & $\begin{array}{c}\text { II } \\
\text { harvest }\end{array}$ & $\begin{array}{c}\text { III } \\
\text { harvest }\end{array}$ & Mean \\
\hline $\mathbf{T}_{1}$ & 2.10 & 2.12 & 2.15 & 2.12 & 122 & 128 & 131 & 127 & 12.71 & 12.83 & 12.76 & 12.77 \\
\hline $\mathbf{T}_{2}$ & 2.17 & 2.18 & 2.20 & 2.18 & 137 & 138 & 145 & 140 & 13.05 & 13.48 & 14.05 & 13.53 \\
\hline $\mathbf{T}_{3}$ & 2.37 & 2.38 & 2.40 & 2.38 & 152 & 159 & 162 & 158 & 14.44 & 14.68 & 15.12 & 14.75 \\
\hline $\mathbf{T}_{4}$ & 2.16 & 2.17 & 2.20 & 2.18 & 133 & 131 & 142 & 135 & 12.75 & 12.88 & 13.16 & 12.93 \\
\hline$T_{5}$ & 2.17 & 2.18 & 2.21 & 2.19 & 128 & 132 & 134 & 131 & 12.78 & 13.1 & 13.22 & 13.03 \\
\hline $\mathrm{T}_{6}$ & 2.28 & 2.30 & 2.32 & 2.30 & 143 & 143 & 148 & 145 & 13.46 & 13.61 & 13.93 & 13.67 \\
\hline$T_{7}$ & 2.39 & 2.42 & 2.44 & 2.42 & 160 & 161 & 169 & 163 & 14.73 & 15.11 & 15.35 & 15.06 \\
\hline $\mathrm{T}_{8}$ & 2.14 & 2.17 & 2.2 & 2.17 & 135 & 139 & 140 & 138 & 12.88 & 12.93 & 13.12 & 12.98 \\
\hline SE (d) & 0.04 & 0.04 & 0.04 & 0.04 & 2.30 & 2.35 & 2.43 & 2.36 & 0.22 & 0.22 & 0.23 & 0.23 \\
\hline CD (0.05) & 0.08 & 0.08 & 0.08 & 0.08 & 4.94 & 5.04 & 5.21 & 5.06 & 0.47 & 0.48 & 0.49 & 0.48 \\
\hline
\end{tabular}




\section{Treatment details}

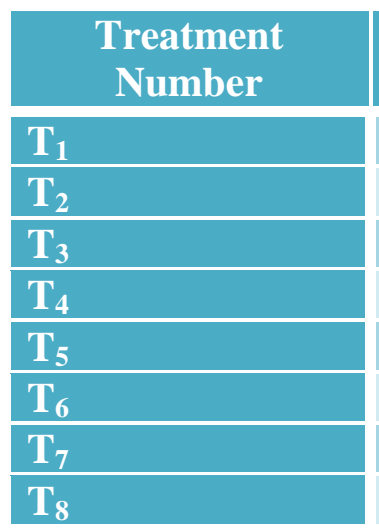

\section{Treatment details}

$100 \%$ Recommended dose of fertilizers (control)

$100 \%$ Recommended dose of fertilizers + Azos + PSB + KSB

$125 \%$ Recommended dose of fertilizers + Azos + PSB + KSB

$75 \%$ Recommended dose of fertilizers + Azos + PSB + KSB

$100 \%$ Recommended dose of fertilizers + PPFM

$100 \%$ Recommended dose of fertilizers + Azos + PSB + KSB + PPFM

$125 \%$ Recommended dose of fertilizers + Azos + PSB + KSB + PPFM

$75 \%$ Recommended dose of fertilizers + Azos + PSB + KSB + PPFM

\section{Water soluble fertilizer schedule}

\begin{tabular}{|c|c|c|c|c|c|c|}
\hline \multirow[t]{2}{*}{ Nutrient } & \multirow{2}{*}{$\begin{array}{l}\text { Recommended } \\
\text { dose of } \\
\text { fertilizer }\end{array}$} & \multicolumn{4}{|c|}{ Time of application } & \multirow{2}{*}{$\begin{array}{c}\text { Total } \\
\text { (kg/ ha) }\end{array}$} \\
\hline & & $\begin{array}{l}20 \text { DAS } \\
\text { (kg/ha) }\end{array}$ & $\begin{array}{l}50 \text { DAS } \\
\text { (kg/ha) }\end{array}$ & $\begin{array}{l}80 \text { DAS } \\
\text { (kg/ha) }\end{array}$ & $\begin{array}{c}110 \text { DAS } \\
\text { (kg/ha) }\end{array}$ & \\
\hline \multirow[t]{3}{*}{$\mathbf{N}$} & $100 \%$ & 67.50 & 67.50 & 67.50 & 67.50 & 270.00 \\
\hline & $125 \%$ & 84.40 & 84.40 & 84.40 & 84.40 & 337.50 \\
\hline & $75 \%$ & 50.60 & 50.60 & 50.60 & 50.60 & 202.50 \\
\hline \multirow[t]{3}{*}{$\overline{\mathbf{P}}$} & $100 \%$ & 36.00 & 4.50 & 2.25 & 2.25 & 45.00 \\
\hline & $125 \%$ & 45.00 & 5.60 & 2.80 & 2.80 & 56.25 \\
\hline & $75 \%$ & 27.00 & 3.40 & 1.70 & 1.70 & 33.75 \\
\hline \multirow[t]{3}{*}{$\mathbf{K}$} & $100 \%$ & 22.50 & 22.50 & 22.50 & 22.50 & 90.00 \\
\hline & $125 \%$ & 28.10 & 28.10 & 28.10 & 28.10 & 112.50 \\
\hline & $75 \%$ & 16.80 & 16.80 & 16.80 & 16.80 & 67.50 \\
\hline
\end{tabular}

Similar results were reported by Hellal et al., (2011) in dill and Soyam et al., (2012) in fenugreek. Bacterial inoculation could improve phosphorus and potassium availability in the soils by producing organic acid and other chemicals by stimulating growth and mineral uptake of plants might lead for better chlorophyll content (Park et al., 2003).

Highest leaf fresh and dry leaf weight was recorded with the application of RDF $125 \%+$ Azos + PSB + KSB + PPFM. Availability of photosynthates and the energy conversion throughout the crop growth has the direct relation with the biomass yield of the crop (Hedge and Srinivas, 1989). Nitrogen, phosphorus and potassium had a dramatic effect on photosynthetic efficiency of the crop and support the vegetative growth. The high biomass yield could also be due to conversion of the unavailable form of nutrients in to available forms, production of siderophores that chelate iron and make it available to the plant root for the energy supply, and synthesis of phytohormones. Microorganisms enhance the $\mathrm{P}$ availability to plants by mineralizing organic $\mathrm{P}$ in soil and by solubilizing precipitated phosphates (Chen et al., 2006). Potassium is one of the important macronutrient element of plant nutrient that plays significant roles in the activation of several metabolic processes, including protein synthesis as well as in resistance to diseases, insects (Rehm and Schmitt, 2002). The potassium is made 
available to plants when the minerals are slowly weathered or solubilized. Mineral potassium solubilization by microbes (KSB) which enhances crop growth and yield. Methylobacterium spp. is known to synthesize plant hormones such as auxins and cytokinins to promote plant growth and these phenomena are recently expressed as mutualism between plants and microorganisms. Anitha (2010) and Meena et al., (2012) documented the production of plant growth promoting substances IAA and cytokinin by Methylobacterium sp. and through induced systemic resistance (ISR) they help to keep the plant healthy.

The increase in calcium, iron and ascorbic acid content in the plants treated with $125 \%$ recommended dose of inorganic fertilizers along with microbial consortium might be ascribed to better availability and uptake of nutrients from soil, which helps in proper metabolic activity in the plan cells. Similar findings were also reported by Mishra et al., (2014) in snow pea pods.

The use of combination of inorganic and biofertilizers not only improve the soil health but also help to maximize sustainable production. It is evident from the results of this study that the uptake and translocation of nutrients in moringa was more pronounced when biofertilizers were inoculated with inorganic nutrients, there by confirming the synergistic interaction between biofertilizers and inorganic nutrients

\section{References}

Anitha, K. G. 2010. Enhancing seed germination of mono and dicotyledons through IAA production of pink pigmented facultative methylotrophs. Trends Soil Sci. Plant Nutr. J., 1: 14-18.

Chen, Y. P., P. D. Rekha, A. B. Arunshen, W. A. Lai and C. C. Young. 2006. Phosphate solubilizing bacteria from subtropical soil and their tricalcium phosphate solubilizing abilities. Appl. Soil Ecol., 34: 33-41
Fahey, J. W. 2005. Moringa oleifera: Review of medical evidences for its nutritional, therapeutic, and prophylactic properties. Part 1. Trees Life J. 1: 5.

Fuglie, L. J. 2001. The Miracle Tree: the Multiple Attributes of Moringa. Church World Service, West African Regional Office, Dakar, Senegal. pp. 103 - 136.

Gowda, K., M. Kempe, Sajjan and B. S. Sreeramm. 2002. Effect of biofertilizers with graded levels of nitrogen and phosphorus on growth, yield and quality of chillies (Capsicum annuum L.) cv. Byadagi dabba. Placrosym, 15: 304-09.

Hedge, D.M.and K. Srinivas. 1989. Optimization of nutrient management in field crops. Indian J. Agron., 34: 180- 34: 184.

Hellal, F. A., S. A. Mahfouz and F. A. S. Hassan. 2011. Partial substitution of mineral nitrogen fertilizer by biofertilizer on (Anethum graveolens L.) plant. Agriculture and Biology J. of North America, 2(4): 652-660.

Johnson, B. C. 2005. Clinical perspectives on the health effect of Moringa oleifera: A promising adjunct for balanced nutrition and better health. KOS Health Publications.

Khan, S and N. Chattopadhyay. 2009. Effect of inorganic and biofertilizers on chilli. $J$. crop and weed. 5(1): 191-196.

Lockett, C. T., C. C. Calvert and L. E. Grivetti. 2000. Energy and micronutrient composition of dietary and medicinal wild plants consumed during drought: Study of Rural Fulani, Northeastern Nigeria. Int. J. Food Sci. Nutr., 51: 195208.

Manivannan, M. I. and J. P. Singh. 2004. Effect of biofertilizers on the growth and yield of sprouting broccoli (Brassica Oleracea var. italica Pelnck) under Allahabad Agro-Climatic conditions. Bioved. 15(1/2): 33-36.

Manzoor, M., F. Anwar, T. Iqbal and M. I. Bhnager. 2007. Physico-chemical characterization of Moringa concanensis 
seed and seed-oil, J. Am. Oil. Chem. Soc., 84: 413-419.

Meena, K. K., M. Kumar, M. G. Kalyuzhnaya, M. S. Yandigeri, D. P.Singh, A. K. Saxena and D. K. Arora. 2012, Epiphytic pink-pigmented methylotrophic bacteria enhance germination and seedling growth of wheat (Triticum aestivum) by producing phytohormone. Antonie Leeuwenhoek, 101: 777-786.

Meena, V. S., Indra Bahadur, Bihari Ram Maurya, Ashok Kumar, Rajesh Kumar Meena, Sunita Kumari Meena, and Jay Prakash Verma. 2016. In: Potassium Solubilizing Microorganisms for Sustainable Agriculture, Springer international publishing Ag: pp.1-20

Mishra, N., P. Mahapatra, S. Mohanty, and M. Pradhan. 2014. Effect of soil amelioration, inorganic, organic and biofertilizers application on yield, quality and economics of snow

Nanthakumar, S and D. Veeragavathatham. 2000. Effect of integrated nutrient management on growth parameters and yield of brinjal (Solanum melongena L.) cv. PLR-1. South Indian J. Hort., 48 (16): 31-35.

Padma Priya, K and Anu Geetham. 2015. A Co - Inoculation Study on the Potential Integrate of Azospirillum and Phosphate Solubilizing Bacteria for Improving Plant Growth and Yield. The Int. J. of Sci \& Tech., 3 (4): 44-49.
Panse, U. G. and P. V. Sukhatme. 1985. Statistical methods for agricultural workers. ICAR Publication, New Delhi. Pp.125-148.

Park, M., D. Singvilay, Y. Seok, J. Chung, K. Ahn and Sat. 2003. Effect of phosphate solubilizing fungi on ' $\mathrm{P}$ ' uptake and growth of tobacco in rock phosphate. Appl. Soil Korean J. Soil. Sci. Fertil., 36: 233-238.

Ponnuswami, V., V. Swaminathan, A. Beaulah, J. Rajangam and B. singh. 2010. Advances in production of moringa: Sri sakthi promotion litho process, Coimbatore.

Rehm, G and M. Schmitt. 2002. Potassium for crop production. University of Minnesota Extension, www.exten sion.umn.edu/ distribution/cropsystems. 46, pp 229

Shams, A. S., H. M. Abd El-Rahman and H. R. El-Ramady. 2013. Evaluation of integrated nutrient management practices for lettuce production under drip irrigation system. J of Appl. Sci. Res., 9(3): 2223-2231.

Soyam, R., Sonali, A. P. Wagh, V. N. Dod, P. K. Nagre and R. M. Gade. 2012. Effect of different biofertilizers on growth, yield and quality of fenugreek. Asian J. Hort., $7(1): 28-30$

Tsaknis, J., S. Lalas, V. Gergis, V. Douroglou and V. Spiliotis. 1999. Characterization of Moringa oleifera variety Mbololo seed oil of Kenya. J. Agric. Food Chem.. 47: 4495-99.

\section{How to cite this article:}

Viji, V., R. Balakumbahan, V. Lakshmanan, R. Poorniammal and Naik, E.K. 2018. Effect of Liquid Bioinoculants and Inorganic Source of Nutrients on Biomass Production and Quality of Annual Moringa (Moringa oleifera Lam.) var. PKM - 1. Int.J.Curr.Microbiol.App.Sci. 7(06): 699-706. doi: https://doi.org/10.20546/ijcmas.2018.706.082 